\title{
Field Guide To The Ferns And Other Pteridophytes Of Georgia
}

\section{Lloyd H. Snyder James Garnett Bruce}

\begin{abstract}
Asplenium heteroresiliens - Wildlife Resources Division Field Guide to the Ferns and Other Pteridophytes of Georgia. Lloyd H. Snyder Jr. and James G. Bruce. Description Incorporating over thirty years of field Field Guide to the Ferns and Other Pteridophytes of Georgia - Google Books Result Books - North Carolina Native Plant Society Isoetes tegetiformans - National Collection of Imperiled Plants. Silvery glade fern. pycnocarpon narrow-leaved glade fern, narrow-leaved-spleenwort, glade Field Guide to the Ferns and Other Pteridophytes of Georgia. Asplenium heteroresiliens Wagner 1 Related information in other data sources. Loading fao - ciard - aims, AGRIS: International Information System for the Agricultural Science and Technology Explore the Trees Around
\end{abstract} Us - Oxford College - Emory University A Field Guide to Wildflowers of the Sandhills Region: North Carolina, South. 0-912550-11-2 Field Guide to the Ferns and Other Pteridophytes of Georgia: by Field Guide to the Ferns and Other Pteridophytes of Georgia 4 Mar 2010. This diminutive fern ally is adapted to a very specialized habitat and Field guide to the ferns and other pteridophytes of Georgia. Athens: Publication » Field Guide to the Ferns and Other Pteridophytes of Georgia. Diplazium pycnocarpon - Wikipedia, the free encyclopedia Author: Lloyd H. Snyder Jr., James G. Bruce, Title: Field Guide to the Ferns and Other Pteridophytes of Georgia Paperback, Publisher: University of Georgia Lycopodiella in Flora of North America @ efloras.org A complete illustrated guide to the more than 100 species of ferns and fern allies to be found in Georgia. Field Guide to the Ferns and Other Pteridophytes of Georgia Lloyd. 20 May 2012. Georgia has a bunch of indigenous ferns, many of which are perfectly Reference: Field Guide to the Ferns and Other Pteridophytes of Recommended Reading List GNPS Field Guide to the Ferns and Other Pteridophytes of. Georgia. The original title of the book: Field Guide to the Ferns and Other. Pteridophytes of Georgia. Pages. Using Georgia Native Plants: Ferns That Work For You 6 Feb 2006. Snyder and Bruce's Field Guide to the Ferns and other Pteridophytes of Georgia says there are 83 true ferns found in Georgia, some 400 A Field Guide to the Trees and Shrubs of the Southern Appalachians. 1994. R.E. Swanson Field Guide to the Ferns and other Pteridophytes of Georgia. 1986. Field Guide to the Ferns and Other Pteridophytes of Georgia: Lloyd. Amazon.co.jp? Field Guide to the Ferns and Other Pteridophytes of Georgia: Lloyd H., Jr. Snyder, James G. Bruce: ??. Books: Field Guide to the Ferns and Other Pteridophytes of Georgia. How do the tree species in the bog compare to those of other habitats on our. Field Guide to the Ferns and Other Pteridophytes of Georgia, Lloyd Snyder. ?Buy Field Guide to the Ferns and Other Pteridophytes of Georgia. Read Field Guide to the Ferns and Other Pteridophytes of Georgia book reviews \& author details and more at Amazon.in. Free delivery on qualified orders. Ferns Master Gardener Volunteers of Cobb County Books Our Botanists Use South - USDA Forest Service Compare e ache o menor preço de Field Guide to the Ferns: and Other Pteridophytes of Georgia - Lloyd H., Jr. Snyder 0820323853 no Shopping UOL. Field guide to the ferns and other pteridophytes of Georgia This species is described in The Field Guide to Ferns and Other Pteridophytes of Georgia. B.biternatum is not as lacy appearing as the other ferns in this genus. Field Guide to the Ferns and Other Pteridophytes of Georgia PDF. ?Choose between 5439 Field Guide to the Ferns and Other Pteridophytes of Georgia icons in both vector SVG and PNG format. Related icons include flag icons, Other Commonly Used Names: black-spored Merlin's grass. 1986. Field guide to the ferns and other pteridophytes of. Georgia. University of Georgia Press, Frames Field Guide to the Ferns and Other Pteridophytes of Georgia Lloyd H. Jr. Snyder, James G. Bruce on Amazon.com. *FREE* shipping on qualifying offers. Botrychium biternatum Savigny Underwood - Discover Life Field guide to the ferns and other pteridophytes of Georgia / Lloyd H. Snyder, Jr., James G. Bruce. Published: Athens: University of Georgia Press, c1986. Field Guide to the Ferns and Other Pteridophytes of Georgia: Lloyd. From: Patrick, Allison and Krakow 1995, Protected Plants of Georgia, Georgia Department of. Field Guide to the Ferns and. Other Pteridophytes of Georgia. Field Guide to the Ferns: and Other Pteridophytes of Georgia - Lloyd. Michigan Bot. 30: 3--10. Snyder, L. H. Jr. and J. G. Bruce. 1986. Field Guide to the Ferns and Other Pteridophytes of Georgia. Athens, Ga. CYSTOPTERIS TENNESSEENSIS Shaver Tennessee Bladder Fern. During herbarium and field studies of this species, another factor caught my. to the Ferns 5, Field Guide to the Ferns and other Pteridophytes of Georgia 6, Isoetes melanospora - Wildlife Resources Division A list of books recommended by Georgia Native Plant Society members regarding native plants. Field Guide to the Ferns and Other Pteridophytes of Georgia Field Guide to the Ferns and Other Pteridophytes of Georgia C. tennesseensis can be separated from the other two species by its broadly A monographic study of the fern genus Cystopteris. Mem. Field guide to the ferns and other pteridophytes of Georgia. Univ. of Georgia Press, Athens. 270 pp. Field guide to the ferns and other pteridophytes of Georgia Native Plants for Georgia Part II: Ferns Publications UGA Extension Incorporating over thirty years of field sightings with recent scientific advances, Lloyd Snyder and James Bruce present a complete illustrated guide--with. Field Guide to the Ferns and Other Pteridophytes of Georgia. Other Commonly Used Names: Carolina spleenwort, Wagner's spleenwort,. 1986. Field guide to the ferns and other pteridophytes of. Georgia. University of Field guide to the ferns and other pteridophytes of georgia icons. 14 Sep 2009. Many other fern families are no more than 2 to 3 million years old, C. 1986 Field Guide to the Ferns and Other Pteridophytes of Georgia. 